\title{
Exploration on the Reform of Accounting Courses for Non-accounting Majors in Economics and Management
}

\author{
Xingyuan HUANG \\ Dalian Polytechnic University \\ School of Management \\ Dalian, Liaoning Province, China
}

\author{
Yangyang SI \\ Dalian Polytechnic University \\ School of Management \\ Dalian, Liaoning Province, China
}

\begin{abstract}
With the rapid development of China's economy, more and more undergraduate colleges and universities of economics and management have regarded accounting as a compulsory course. However, for non-accounting students, the purpose of their study is obviously not for accounting, and although it is for the School of Economics and Management, but because of the strong professionalism of accounting, for non-accounting students, learning the difficulty is great. Therefore, this paper explores the problems faced by the non-accounting students in the accounting and accounting courses, and finds that the following problems are not clear: the teaching objectives are not clear, the curriculum system is not reasonable, the teaching methods are unreasonable, and the accounting related teaching materials lacking non-accounting majors. To this end, it is proposed how to solve the problem through the reform of the course teaching, and the solution is also the innovation point of this research.
\end{abstract}

Keywords-economics and management; non-accounting major; curriculum reform

\section{INTRODUCTION}

Accounting as a universal "business language" plays an important role in business management and economic decision-making. With the rapid development of the economy and the accelerated changes in the market cycle, the demand for knowledge of accounting personnel is becoming stronger and stronger. In order to meet the market demand, many colleges and universities of non-accounting majors offer a series of accounting courses ${ }^{[1]}$. Although the starting point is good, the non-professional students do not consider the purpose of accounting knowledge, the courses offered are not applicable. So the students waste a lot of energy, the effect is not satisfactory. This paper hopes to promote the reform of education by discussing the existing problems and proposing targeted recommendations.

\section{Problems In the Teaching OF Non-AcCounting MAJORS IN ECONOMICS AND MANAGEMENT}

\section{A. The teaching goal is not clear}

At present, many non-accounting students in colleges and universities arrange students to study "basic accounting", "financial accounting", "financial management", "cost accounting" and other courses. However, these courses are generally set to "make students understand and master accounting"[2]. The basic principles, basic skills and basic methods of accounting, and the ability to perform simple accounting practices." The key is to train students how to become an accountant and account for accounts, while ignoring the characteristics of non-accounting students, their goal should not be accounting, but should be accounting. Moreover, under this teaching goal, students tend to focus on cumbersome and difficult to digest calculations, and it is difficult to study the financial situation of the company through data after it is calculated ${ }^{[3]}$.

\section{B. The curriculum system is not set properly}

Due to the wrong positioning of the teaching objectives, the course arrangement has problems. Most of the non-accounting majors in colleges and universities are arranged according to the basic courses of accounting majors. The courses are mostly basic courses such as Basic Accounting and Accounting, but the courses are for accounting students. Laying the foundation for subsequent deeper content learning is not appropriate for non-accounting students ${ }^{[4]}$. Because the main content of basic accounting and other textbooks is liberation in the preparation of accounting subjects, most of the non-accounting students who do not charge accounting professions will not engage in accounting professions, but in other management professions, these professions do not have to master the accounting subjects, and It is necessary to understand the meaning of accounting subjects and look at accounting statements. However, at present, most non-accounting professional courses in colleges and universities do not include accounting statements in the curriculum system. As a result, non-accounting students overcome the difficult problems and have little use. They not only make students difficult but also waste the educational resources of colleges and universities.

\section{Teaching methods are unreasonable}

In colleges and universities, the lectures on non-accounting majors in economics and management are generally based on lectures and practical lessons. The lecture is a cramming style, which is rarely interactive. It is more difficult for non-professional students who have difficulty learning and inhibits their interest in learning. The practical lesson is mainly to fill in various reports, so that the books can be analyzed 
according to the company case. The fun and interesting curriculum of various problems has become a difficult and uninteresting course for pure accounting and accounting entries. This teaching method is out of line with the practice of the enterprise, lacking typical case teaching, further damaging the enthusiasm of students and affecting the teaching effect.

\section{Lack of non-accounting professional accounting related teaching materials}

At present, most accounting related textbooks on the market are aimed at accounting majors. The content of accounting focuses on the combination of basic accounting and financial accounting. Specifically, it is to learn the basic principles of accounting and the contents of the debit and credit accounting method, and includes the contents of the accounting methods of assets, liabilities, owner's equity, income, expenses and profits, and simple financial statements. Introduction. The textbook of this structure is not applicable to students of non-accounting majors in economics and management. The reason is that there are too many textbooks, teachers will focus on accounting, weaken the analysis and interpretation of financial statements and how to use financial statements to make decisions, and the curriculum objectives are reversed.

\section{The MANAgEMENT OF NON-ACCOUNTING PROFESSIONAL COURSES IMPROVEMENT MEASURES}

\section{A. Clarify teaching objectives and priorities}

In the non-accounting professional "Accounting" course teaching, the teaching goal should be "to analyze and use the financial status, business results and cash flow information through financial statements", that is, to train students to "know accounting" rather than "as accounting" ${ }^{[5]}$. The analysis and use of accounting-related information as the goal of teaching, then in the specific teaching arrangements: should focus on understanding financial statements, rather than focusing on the calculation of each number in the accounting table; should be students can ultimately science Reasonable use of the information of the accounting statements to make relevant corporate decision-making as the evaluation criteria, rather than calculating the report data correctly as the assessment criteria.

\section{B. Arrange the teaching system reasonably}

After determining the teaching objectives and priorities according to the real needs of non-accounting students, the teaching system will be arranged. Domestic universities can refer to and learn from the model of non-accounting professionals in the United States and the United States, and innovate teaching content. In China, universities have innovated the curriculum system arrangement for non-accounting majors, integrated the contents of financial accounting and management accounting, and added courses related to financial statement analysis to improve students' ability to analyze reports and make decisions. At the same time, the curriculum design should consider the length of time. Non-accounting students have no professional accounting students in these accounting courses. Therefore, they should arrange the course time reasonably, and focus on the more practical content of the non-accounting students in the economic management class. Increase students' interest in learning.

\section{Optimize teaching methods and focus on actual cases}

Accounting is a discipline that is closely integrated with practice. In accounting teaching, it is even more necessary to increase practical cases to enhance students' enthusiasm for learning, especially for non-accounting students in economics and management. Under the traditional "teacher, student listening" mode, the method of case teaching should be greatly increased. For example, the teacher tells the students a real case, gives the company's current financial statements, and lets the students discuss the current financial situation of the company and make reasonable decisions ${ }^{[6]}$. After the group discussion, reasonable business design should be carried out according to the company's current situation, clarify the business results and profit and loss, and report and explain in the classroom. Through this case study, not only can students improve their participation and enthusiasm, but they can also develop their interest in accounting. Moreover, the content of the practical case teaching is no longer the accounting and accounting entries, but the non-accounting students in the management class can gain a deeper understanding of the meaning and role of the information in the financial statements, so as to continuously learn how to conduct science according to this. decision making.

\section{Compile supporting non-accounting professional textbooks}

Accounting textbooks are especially important for students' teaching. Especially for students who are non-accounting majors in economics and management, it is difficult to learn this highly specialized and obscure subject. If the preparation of textbooks is unreasonable. Or, if you use the textbooks of accounting majors at will, it is more difficult to understand and deviate from their learning goals. On the contrary, good teaching materials can make students' learning have a basis, enhance the systemic and complete learning, and meet their learning goals. It can be seen that it is particularly important to compile textbooks that are compatible with the non-accounting majors of economics and management.

In the preparation of teaching materials, we must follow the direction of the teaching objectives, pay attention to "understanding accounting" rather than "accounting", that is, content writing should focus on explaining the understanding of the financial statement information, the role, how to extract this information, And how to apply it to corporate decision-making after extracting information. In addition, case studies and exercise exercises should be added. Through simple and interesting cases, students can more easily absorb and absorb the corresponding knowledge, and increase the fun of learning; through the exercise of exercises, further consolidate and deepen the understanding of knowledge.

\section{SUMMARY}

In summary, the current accounting courses for non-accounting majors in economic management often have many problems in the setting of teaching objectives, the arrangement of teaching contents, the design of teaching methods and the selection of teaching materials. However, the 
state is continuously advancing education reform. Many economic and management colleges are also constantly practicing and exploring the curriculum reform of non-accounting majors. Combining the needs of teaching objects with their own characteristics, formulating clear and reasonable teaching objectives, and constantly improving the curriculum teaching system. Enrich teaching methods, increase case teaching, and actively solve current problems. Inspire students' subjective initiative, so that non-accounting students in economic management can combine abstract and profound theoretical knowledge with vivid and rich corporate practices to learn accounting courses so that they can use the knowledge they have learned to grow into Qualified talents adapted to economic and social development.

\section{REFERENCES}

[1] Jane R. Williams et al. Accounting - the basis of corporate decision-making [M]. Du Meijie translation. Beijing: Mechanical Industry Press, 2011. (In Chinese)

[2] Cheng Yong. Reflections on Accounting Teaching System and Teaching Methods [J]. Accounting Research, 2016 (4): 191-192. (In Chinese)

[3] Zhou Shuqin, Shao Guozhu of accounting professional teaching methods [J] Chinese management information, 2016 (9): 257. (In Chinese)

[4] TAN Chunmei. Reflections on the Teaching Reform of Accounting Courses for Non-Accounting Majors[J].Rural Economy and Technology,2017,28(20):76. (In Chinese)

[5] Chen Juan. Exploration of accounting teaching thinking and teaching content in non-accounting majors [J]. Contemporary Accounting, 2017, (09): 69-70. (In Chinese)

[6] Liu Xiaoling. The Integration of Management Accounting and Financial Accounting: A Study on the Teaching Reform of Non-Accounting Professional Accounting Courses [J]. Business Accounting, 2016, (03): 117-119. (In Chinese) 